\title{
Stakeholder Management Strategies: The Special Case of Universities
}

\author{
Germaine Chan ${ }^{1}$ \\ ${ }^{1}$ Department of Business and Tourism and Hospitality Management, Mount Saint Vincent University, Halifax, \\ Nova Scotia, Canada \\ Correspondence: Germaine Chan, Department of Business and Tourism and Hospitality Management, Mount \\ Saint Vincent University, Halifax, Nova Scotia, B3M 2J6, Canada. E-mail: germaine.chan@msvu.ca
}

Received: March 2, 2021

doi:10.5539/ies.v14n7p12
Accepted: April 7, $2021 \quad$ Online Published: June 23, 2021

URL: https://doi.org/10.5539/ies.v14n7p12

\begin{abstract}
Universities must secure stakeholder support to ensure the successful implementation of most initiatives. However, given the shared governance structures and collegial cultures of many universities, what strategies do university leaders enact to obtain stakeholder support? Although several stakeholder management and organizational response models have been proposed, there is limited empirical research on the actual strategies university leaders use to secure stakeholder support. This study focuses mainly on university academics - a powerful, autonomous, and intelligent stakeholder group whose support for most higher education initiatives is essential. Guided by a theoretical stakeholder management model, this research examines the strategies university leaders employ to manage this salient and sometimes adversarial group with respect to a major organizational change initiative. The evidence shows that university leaders use strategies that centre mostly on themes of shared goals, consensus, partnerships and engagement, which align with the strategies proposed by the theoretical model. However, to manage non-supportive stakeholders peer influence is enacted rather than the defend strategy recommended by the theoretical model. As a result, this study contributes to stakeholder management theory and proposes a revised stakeholder management model that is particularly applicable to the higher education sector.
\end{abstract}

Keywords: stakeholder management, stakeholder management strategies in higher education, social networks in higher education, organizational responses in higher education, performance management in higher education

\section{Introduction}

Securing stakeholder support is key for the successful implementation of most organizational initiatives, and without this support many projects will fail (Berman \& Wang, 2000; Borgianini, 1998). This is especially true of large-scale projects that may significantly alter how an organization's activities are conducted. Indeed, research has shown that increasing stakeholder support is linked to improved performance (Henisz et al., 2014). However, it is not unusual for stakeholders to have divergent, even adversarial, views on particular issues. To this point, Frooman (1999, p. 193) argued that "stakeholder theory is about managing potential conflict stemming from divergent interests." Numerous studies have examined situations in which stakeholders had varying preferences. For example, Yamane and Kaneko (2021) examined stakeholder preferences for corporate behavior relating to sustainable development goals. Thompson and Friess (2019) investigated stakeholder preferences for the sustainable development and conservation of mangrove forests, and Schito et al. (2019) identified stakeholder preferences for where power lines should be installed in communities. As well, Baba and Hakem-Zadeh's (2012) conceptual theory of evidence-based decision-making proposes that stakeholder preferences influence whether evidence is used for decision-making purposes.

Therefore, stakeholders may have divergent views. Some may support a certain organizational initiative while others oppose it. Some may be neutral on the initiative, and others have the equal potential to be supportive or non-supportive. Ideally, management would want support from all stakeholders, especially from their primary stakeholders (Mitchell et al., 1997). Thus, management must develop strategies to manage differing and sometimes adversarial stakeholder views on a variety of issues. Non-supportive stakeholders who are seen as having a high potential for threat and a low potential for cooperation are of particular concern to organizations, and are the group about whom managers worry the most (Mitchell et al., 1997). As discussed in the literature review below, several frameworks for organizational responses to stakeholders have been proposed. However, there is a dearth of studies focusing on the response strategies organizations have actually enacted to counter stakeholder pressures and demands (Aaltonen \& Sivonen, 2008; Parmar et al., 2010). 
Stakeholder management studies have been conducted in several sectors and industries such as festivals (see Andersson \& Getz, 2008), construction (see Chinyio \& Olomolaiye, 2009), private/public partnerships (see El-Gohary et al., 2006), oil and gas (see Waritimi, 2012), healthcare (see Harrison \& Thompson, 2014) and global projects (see Aaltonen \& Sivonen, 2008) to name only a few. Yet, there is very little research on stakeholder management strategies employed in the higher education sector. It is important to examine this sector because of its unique organizational structure. Traditionally, universities have been described as loosely coupled organizations in which connections between different professional groups are loose and the academic staff are autonomous (Honkimäki et al., 2021). Furthermore, higher education is one of very few sectors that employs a shared governance model under which the affairs of a university are managed both by faculty members and board members (Patria, 2012). Mintzberg (1980) characterized universities as professional bureaucracies in which work is largely coordinated by requiring individuals to possess a certain standard of skills, usually before they begin to do the work. Mintzberg (1980) further argued that much of the formal and informal power of the professional bureaucracy rests in its operating core, and that professionals control their own work and tend to maintain collective control of the administrative apparatus of the organization. As well, it has also often been said that managing faculty members is as difficult as herding cats, because faculty members are highly independent professionals who have a high degree of control over their work (Mintzberg, 1980).

Another reason to study stakeholder management in higher education is the well-documented call for substantive change in the sector (see Cavanaugh, 2018; Chamorro-Premuzic \& Frankiewicz, 2019; Dennis, 2020; Pincus et al., 2017). Many universities across Canada and around the globe are in crisis (Austin- Smith, 2020; Kawamorita et al., 2020) with challenges to the traditional model of higher education coming from many quarters (Kimberly \& Bouchiki, 2016). For example, as tuition fees continue to rise, politicians have begun to question the efficiency of university management, particularly in publicly funded institutions (Kimberly \& Bouchiki, 2016). Specifically, many universities are in dire financial conditions due to factors, such as increased costs, decreased government funding, intense competition for students and the COVID pandemic, to name just a few (Dickler, 2020; Freisen, 2020; Schifrin \& Tucker, 2021). Indeed, tremors continue to reverberate throughout the sector following Laurentian University's move to file for protection from creditors in February 2021 - a first in the history of Canadian universities (CBC, 2021). Over 60 programs were closed, and 100 professors dismissed and as a result, the financial health of all Ontario universities is being scrutinized (Friesen, 2021). Given the state of the higher education field and the changes that are being demanded, university leaders will need to obtain support from as many stakeholders as possible to implement change. Research in the area of stakeholder management in higher education is thus essential in order to identify, and understand why, which strategies are the most successful for securing stakeholder support. Therefore, to fill these gaps, this exploratory study asks, and seeks to answer, the following research question: What are the stakeholder management strategies used by university leaders to manage faculty members' reactions to major organizational initiatives?

The setting for this project is the Canadian university sector, and the organizational issue under discussion is performance management (PM), which is now a reality for many universities around the globe. From a structural perspective, although PM systems can be configured in a variety of ways, they are essentially systems and philosophies that include a shared vision, teamwork, training, and incentives that are linked to performance measurement (Lebas, 1995). In turn, performance measurement is defined as a set of metrics that quantify the efficiency and effectiveness of actions and are designed to support PM (Bourne et al., 2003). Performance information, sometimes referred to as indicators or key performance indicators, is the result of performance measurement. PM was first introduced to higher education and other public institutions in OECD (Organization for Economic Co-operation and Development) countries in the early 1980s and is often implemented as part of a broader reform strategy commonly referred to as New Public Management (NPM), an approach intended to make public sector organizations more efficient and effective (Alonso et al., 2015; Craig et al., 2014). Although PM systems are commonplace in higher education, they have been widely criticized by many academics, especially with respect to measuring academic performance (see Alvesson \& Spicer, 2016; Birdsall, 2018; Craig et al., 2014; Kairuz et al., 2016; Kalfa et al., 2018; Kallio et al., 2016; Kenny, 2017). An example of how divisive and controversial PM systems can be occurred at one of Canada's largest research universities. In 2016, faculty members at the University of Manitoba went on strike after, according to the faculty union, the university failed to make a single meaningful, acceptable offer on the union's main priorities, one of which was protection from performance indicators (CBC News, 2016). The administration's response was to compromise, which resulted in a deal to limit the use of performance metrics in assessing performance (McGuckin, 2016). 


\section{Literature Review}

\subsection{Stakeholder Management}

Stakeholder management is a natural extension of stakeholder theory, developed by Freeman (1984). The theory proposes that organizational success depends not only on profit maximization but also on attending to the needs and expectations of various stakeholders. More precisely, stakeholders are defined as any person or group than can affect, or be affected by, an organization's activities.

Scholars have identified two general rationales - economic and normative - to explain why organizations engage in stakeholder management. The economic rationale views stakeholder management as a beneficial system that improves decision-making (De Colle, 2005) and strengthens reputations and relationships (Fishcher \& Reuber, 2007). In other words, organizations link these benefits with improved economic performance. The normative rationale views stakeholder management as a system motivated by an organization's moral orientation and institutional views (Friedman \& Miles, 2006) to contribute to the common good or to promote principles of equitable justice (Phillips, 1997).

There has also been considerable debate about which stakeholder groups should be prioritized. When stakeholder theory was introduced, it was considered to be opposed to the shareholder view but since then the discussion has evolved and now recognizes that stakeholders and shareholders are not competing objectives but mutually beneficial ones (Berman et al., 1999). One approach involves classifying stakeholders, determining their importance and establishing consensual relationships with those that are the most important. Indeed, most organizations still tend to focus their attention on known, salient or powerful groups to protect their advantages in existing businesses (Hart \& Sharma, 2004). An alternative approach views stakeholder management as an act of balancing the needs of multiple constituents, not only the primary or powerful stakeholders. Hart and Sharma (2004) expanded this concept and suggested that in order to manage disruptive change and access knowledge to generate competitive imagination, organizations may want to look beyond established stakeholder networks, such as, for example, fringe stakeholders.

\subsection{Organizational Response Frameworks}

A number of frameworks have proposed various organizational responses or stakeholder management strategies to respond to certain stakeholder groups. However, Ali (2018) argued that only a proactive orientation may be regarded as an authentic stakeholder management strategy. Such an orientation requires an attempt to understand and satisfy the latent needs of stakeholders (Casablancas-Segura \& Llonch, 2016). Ali (2018) found that stakeholder/proactive firms support a specific philosophy, attempt to create long-term relationships with their stakeholders based on cooperation, collaboration, transparency and communication, and engage stakeholders in meaningful dialogues to reach consensual solutions to common issues of concern. Alternatively, Casablancas-Segura and Llonch (2016) proposed that an organization could also adopt a responsive stakeholder orientation, which attempts to understand and satisfy the expressed or stated needs, not the latent needs, of stakeholders.

Gupta et al. (2020) examined two specific stakeholder groups - shareholders and employees - in various institutional and firm-level environments. The result was a typology of four possible stakeholder engagement strategies: complimentary, substitutionary, minimalist and encompassing. Complimentary stakeholder engagement focuses on serving the interests of employees whereas substitutionary engagement focuses on shareholders. However, organizations can choose to adopt a minimalist approach and do only what is necessary as required by law, or adopt an encompassing strategy under which both stakeholder groups receive maximum attention. Gupta et al. (2020) predicted that the stakeholder management strategy a firm adopts towards shareholders and employees will be driven by the type of institutional environment (labor- or market-driven) and firm-level characteristics such as the need for specialized labor, ownership concentration and level of internationalization.

Another stakeholder management model, proposed by Preble (2005), offers several generic approaches that could be used for a variety of stakeholder types, issues and industry situations. Response strategies include direct and open communication for definitive stakeholders, strategically important stakeholders, dangerous stakeholders who threaten direct confrontation/sabotage and stakeholders who are not clearly understood by the organization. When conflicts are not easily resolvable, negotiation with the assistance of a mediator is recommended. Preble's (2005) model also recommends a continuous monitoring of stakeholder positions.

Oliver (1991) identified five strategies - acquiescence, compromise, avoidance, defiance and manipulation - that organizations may enact as a response to institutional pressures. These response strategies can also be applied to 
stakeholders. Acquiescence includes mimicking institutional models, obeying rules and accepting norms. From a stakeholder point of view, this would result in an organization acquiescing to stakeholder demands and preferences. Compromise strategy can be enacted by balancing the expectations of multiple constituents, placating and accommodating, and negotiating with institutional stakeholders, which was the case for the University of Manitoba, as discussed above. The avoidance response can include loosening institutional attachments, disguising nonconformity or changing goals, activities or domains. An organization can also choose to adopt a defiance response by ignoring explicit norms and values, contesting rules and requirements and assaulting the sources of institutional pressures, or in this study's case, stakeholder pressures. A manipulative strategy requires organizations to shape values and criteria and dominate institutional constituents (or stakeholders) and processes.

Clarkson (1995) proposed that corporate social performance is best evaluated by how an organization manages its relationships with stakeholders and characterized corporate responses as either reactive, defensive, accommodative or proactive. The reactive response involves denying responsibility and doing less than required. The defensive response calls for admitting responsibility but fighting it at the same time and doing the minimum that is required. An accommodative response entails accepting responsibility and doing all that is required whereas a proactive posture anticipates responsibility and doing more than is required.

Mampaey and Huisman (2016) focused on defensive stakeholder strategies in European universities and made a distinction between effective (conflict-reducing) and ineffective (conflict-inducing) defensive strategies. Conflict reducing strategies combine acknowledgement and recognition of the controversial actions with institutional justifications, excuses and apologies. Conflict-inducing strategies may include a combination of mere denial, mere technical arguments and institutional arguments. Mampaey and Huisman (2016) hypothesized that corporate-type universities would tend to employ more conflict-inducing defensive strategies towards stakeholders.

\subsubsection{Guiding Framework}

The framework used in this study was developed by Savage et al. (1991). Although it does overlap with some of the frameworks discussed previously, this particular one was selected because it applies to all stakeholders, identifies the possible positions a stakeholder group may take and proposes a stakeholder management strategy/organizational response for each position. The framework calls for an assessment to evaluate whether stakeholders have the potential to either threaten or cooperate with an organization regarding a specific issue. Points to consider in this assessment include the extent to which stakeholders control key resources, the level of power they have as compared to the organization, the likelihood of taking supportive or unsupportive action and the likelihood of forming coalitions with other stakeholders or organizations. Based on the assessment, stakeholders are put into one of four classifications: supportive, marginal, non-supportive and mixed blessing. Then, depending on the classification, one of four stakeholder management strategies, discussed below, is proposed. Supportive stakeholders are what every organization wishes for: these stakeholders support organizational goals and actions and score high on potential cooperation and low on potential threat. The model proposes that the best strategy for this supportive group is to involve them as much as possible in the issues in which they believe. Marginal stakeholders are considered neutral; their interests are specific and narrow, and they tend to ignore all other issues. They are neither highly threatening nor especially cooperative, although they have the potential to become either or both. The recommended strategy is to monitor the group for their reactions, if any, to strategic issues. When a stakeholder group's potential for threat and cooperation are equal, they are referred to as mixed-blessing stakeholders. They may shift out of their equilibrium position and become either more cooperative or more threatening. In these cases, a collaboration strategy is recommended to maximize cooperation and make potential opposition more difficult. Non-supportive stakeholders are considered to have a high potential for threat and a low potential for cooperation. They are the group that organizations and managers worry about the most. The proposed strategy for non-supportive stakeholders is a defensive approach that borrows from traditional marketing and strategic tactics to handle competitors, although the long-term objective should be to find a way to bring non-supportive stakeholders onto the organization's side. A summary of the framework is presented in Table 1. 
Table 1. Summary of model for assessing and managing organizational stakeholders (Savage et al., 1991)

\begin{tabular}{|c|c|c|c|}
\hline $\begin{array}{l}\text { Type of } \\
\text { Stakeholder }\end{array}$ & Characteristics & Threat/Cooperation & $\begin{array}{l}\text { Stakeholder } \\
\text { Management } \\
\text { Strategy }\end{array}$ \\
\hline Supportive & $\begin{array}{l}\text { Ideal stakeholder; supports organizational goals and actions; } \\
\text { usually includes board members, managers and staff } \\
\text { employees }\end{array}$ & $\begin{array}{l}\text { Low on potential threat/high on } \\
\text { cooperation }\end{array}$ & Involve \\
\hline Marginal & $\begin{array}{l}\text { Not usually concerned about most issues; may include } \\
\text { stockholders and consumer interest groups depending on the } \\
\text { issue }\end{array}$ & $\begin{array}{l}\text { Neither highly threatening nor } \\
\text { highly cooperative }\end{array}$ & Monitor \\
\hline $\begin{array}{l}\text { Mixed } \\
\text { Blessing }\end{array}$ & $\begin{array}{l}\text { Play a major role in organization; can transition to a } \\
\text { non-supportive or supportive position }\end{array}$ & $\begin{array}{l}\text { High on potential threat/high } \\
\text { on cooperation }\end{array}$ & Collaborate \\
\hline Non-supportive & $\begin{array}{l}\text { Most distressing for an organization and its managers; usually } \\
\text { includes labour unions, governments and sometimes the news } \\
\text { media }\end{array}$ & $\begin{array}{l}\text { High on potential threat/low on } \\
\text { cooperation }\end{array}$ & Defend \\
\hline
\end{tabular}

\section{Materials and Method}

To examine stakeholder management strategies in the higher education sector, this exploratory study has adopted a qualitative approach, because such an approach allows for a deeper understanding of certain aspects of organizational life. More specifically, the qualitative approach answers questions that relate to the "what," "how" and "why" of a particular phenomenon, rather than the "how many" or "how much" questions, which are normally best answered by quantitative methods (McCusker \& Gunaydin, 2015). As the goal of this study was to determine the what, how, and why of stakeholder management strategies in higher education, a qualitative approach is justified.

\subsection{Data Collection}

To investigate the research question, this study used two sources of data: semi-structured interviews and qualitative responses to an open-ended survey question. The data are from a larger study conducted on PM in the Canadian higher education sector (see Chan, 2018). Semi-structured interviews were conducted because they can provide rich data for understanding participants' experiences (Rubin \& Rubin, 2011). The interviews first focused on obtaining respondents' general perceptions of PM in higher education, and then on the strategies used to move the PM agenda forward. The open-ended survey question asked respondents to comment on how they dealt with stakeholder pressure with regard to the use of PM in their units.

\subsection{Selection of Respondents and Response Rates}

Respondents were selected using a purposive sampling technique, which is defined as "selecting units (e.g., individuals, groups of individuals or institutions) based on specific purposes associated with answering a research study's questions" (Teddlie \& Yu, 2007). This technique is often used to identify and select information-rich participants for the most effective use of limited resources (Patton, 2002) and provides greater in-depth findings than other probability sampling methods (Cohen et al., 2011).

Invitations to participate in the survey, which contained one open-ended question, were sent to all 71 public, non-denominational, English-speaking Canadian universities. Of these, 28 universities agreed to participate, 7 declined, and 36 did not respond. A total of 425 surveys were sent to every senior administrator (dean level and above) of the 28 universities. A total of 86 participants responded to the survey, 14 of whom answered the open-ended survey question, the results of which were used in this study.

A total of 15 individuals were interviewed for this study. These respondents included a mix of faculty and administrators, all of whom were familiar with PM in Canadian higher education. The interviews lasted, on average, one hour each, and all but one was audio-recorded. The sample size for interviews typically relies on the concept of "saturation," the point at which no new themes are observed in the data. This can occur in a sample size of 12 if the group is homogeneous and familiar with the issue being examined (Guest et al., 2006), which was the case in the study.

In summary, the data used to answer the research questions consisted of 15 interviews and 14 responses to an openended survey question. The combined profile of respondents and their locations in Canada is shown in Table 2. 
Table 2. Profile of respondents

\begin{tabular}{cccccc}
\hline Position of Respondents & No. & Per cent & Location of Respondents & No. & Per cent \\
\hline Vice President & 6 & 20.69 & Central Canada & 21 & 72.41 \\
(includes Assistant \& Associate) & 6 & & Western Canada & 7 & 24.14 \\
Executive Director & 4 & 13.79 & Atlantic Canada & 1 & 3.45 \\
Dean & 8 & 27.59 & & & \\
Professor & 7 & 24.14 & & & \\
Director & 2 & 6.89 & & & \\
Librarian & 1 & 3.45 & & 29 & $100 \%$ \\
Administrator & 1 & 3.45 & & &
\end{tabular}

\subsection{Data Analysis}

All interviews were transcribed, and both these and the answers to open-ended survey questions were analyzed and coded to develop major themes. All the transcripts were first read several times to obtain a general first impression. A micro-examination of each transcript was then conducted line-by-line and word-by-word in order to form initial categories or themes. Then, the initial categories were analyzed in more detail to gain new knowledge about them and how they relate to other categories. Throughout the entire process, all impressions, coding decisions and thought processes were recorded in detailed notes.

\subsection{Research Quality}

Attaining trustworthiness, or validity and reliability, should be an important objective of all qualitative research. However, because concepts of validity and reliability cannot be addressed for qualitative research in the same way as for quantitative research, other strategies are necessary. Guba (1981) proposed four criteria that should be considered to ensure the trustworthiness of a qualitative study: credibility, transferability, dependability and confirmability.

Credibility refers to confidence in the ability of the data and processes of analysis to address the intended focus and requires that the results align well with reality (Shenton, 2004). Transferability is the extent to which the findings can be applied and/or modified to another setting or group. According to Lincoln and Guba (1985), dependability seeks ways to account for factors of instability and can be demonstrated using an audit trail, code-recode strategy to determine whether results are similar (Chilisa \& Preece, 2005). Confirmability, equivalent to objectivity, is achieved when readers are assured that the findings of the study reflect the experiences of the informants, rather than the preferences of the researcher (Shenton, 2004). Miles and Huberman (1994) noted that a key criterion for confirmability is the extent to which the researcher admits his/her own predispositions. The strategies used to demonstrate credibility, transferability, dependability and confirmability are shown in Table 3.

Table 3. Strategies used to achieve qualitative research quality (Adapted from Shenton, 2004)

\begin{tabular}{lll}
\hline $\begin{array}{l}\text { Quality } \\
\text { criterion }\end{array}$ & Overall strategies to achieve each quality criterion & $\begin{array}{l}\text { Specific strategies and tactics used to achieve each quality } \\
\text { criterion }\end{array}$ \\
\hline Credibility & Use appropriate well-recognized research methods & $\begin{array}{l}\text { The study used interviews and open-ended survey questions, both } \\
\text { of which are well-recognized research methods. }\end{array}$ \\
\hline $\begin{array}{l}\text { Develop early familiarity with culture of participating } \\
\text { organizations }\end{array}$ & $\begin{array}{l}\text { Familiarity with the culture of participating organizations was } \\
\text { achieved through conversations and research. Additionally, the } \\
\text { investigator has worked in higher education for over 30 years and } \\
\text { is very familiar with higher-education culture. }\end{array}$ \\
\hline Employ tactics to help ensure honesty of participants & $\begin{array}{l}\text { Participants were given assurance of total anonymity and the } \\
\text { option to refuse to participate. They were encouraged to be frank } \\
\text { and open, and were assured of the investigator's independence. }\end{array}$ \\
\hline $\begin{array}{l}\text { Member checks of data collected, } \quad \text { and } \\
\text { interpretations/theories formed }\end{array}$ & $\begin{array}{l}14 \text { of the 15 interviews were audio recorded, thus increasing the } \\
\text { accuracy of data. If responses were not clear, respondents were } \\
\text { contacted again to clarify (3 cases). }\end{array}$ \\
\hline Thick descriptions of phenomenon under scrutiny & $\begin{array}{l}\text { The study (Chan, 2018) includes detailed descriptions of the } \\
\text { actual situation and context. }\end{array}$ \\
\hline
\end{tabular}


The study (Chan, 2018) contains detailed descriptions of the

Provide background data to establish context of study and detailed description of phenomenon in question to allow comparisons to be made

Purposeful sampling \& detailed descriptions phenomenon, and a detailed discussion of the Canadian higher education sector.

All respondents chosen were particularly knowledgeable of the issues under investigation.

Research provides adequate quotations to support results.

The study (Chan 2018) includes detailed descriptions of how the study was carried out, including operational detail of data gathering.

be repeated

Use of reflexive journal to document investigator's personal

Admission/acknowledgement of researcher's beliefs and assumptions reflections in relation to the study.

\section{Results}

\subsection{Mixed Support for Performance Management}

All the interview respondents agreed that performance management was a major organizational initiative, and that it was and still is controversial. The respondents indicated that of the stakeholder groups, faculty were the most likely to resist PM, especially for evaluating teaching and research performance:

Most of the pushback comes from faculty. They say what we do is not measurable and recoil at the idea of being considered as factory line assembly producers of students. There is also some pushback from staff, but not as much as faculty - some of them come from industry, so they may be used to KPIs. Students are the most open to KPI data. It allows them to evaluate and compare institutions...they've created the ultimate KPI-Rate My Professor.

Interview respondent \#1 (Dean)

Some faculty find it very difficult to articulate the value of what they do in terms that board members understand...I think that some academics feel as if they were hired to think and teach but not necessarily to report back on that.... On the other hand, governments, boards, and students are asking universities to show evidence that they are doing work that is appropriate and aligned with their strategic goals and showing evidence of improvement over time.

Interview respondent \# 2 (VP Academic)

We have an anti-KPI culture. It is very invasive - if you know what I do then you have a lot of power over me. There is a natural resistance to personal measurement.

Interview respondent \# 6 (Faculty)

The findings also indicate that faculty resistance is not absolute, and that it is largely inactive. In other words, some faculty members oppose PM, while others support PM, and still others show only some support for PM:

In principle I would be in favor of being able to track performance in terms of what goes on in departments and business schools or universities, but I would suspect that most faculty members do not like being watched and measured if you spent all your life not being watched or measured.

Interview respondent \#3 (Faculty)

I think all faculty members feel two ways about it. ... I think you get mixed reactions...

Interview respondent \#4 (Executive Director)

I think KPIs are good; but I don't think it comes without problems... I haven't seen any active resistance, though.

Interview respondent \#5 (VP Academic)

\subsection{Professors Are the Bosses, and They Command Respect}

Several respondents commented on the absence of a supervisor-subordinate relationship. Faculty respondents did not view university administrators as their bosses, but rather saw themselves as the bosses. Indeed, the notion of taking orders from university administrators was a non-starter for all respondents:

If you are president of the Royal Bank, you can tell me what to do, but if you are president of my university, you don't tell me what to do. What I do has nothing to do with you, actually. For example, he doesn't tell me to come and work in the office. He is not the one who tells me to 
publish in that particular journal. He can help me with funding, but what does he do when I am in the classroom?... You do want faculty buy-in, but the issue is that we do not view the dean or the provost, or even the president, as our bosses... there is a certain collegial dimension.

Interview respondent \#3 (Faculty)

The profs are basically the bosses, right? They are tenured; they are there forever; therefore, there is not much a president, or provost, or dean can do.

Interview respondent \#10 (Faculty)

My department chair is a colleague, not my boss. He can't tell me what to do.

Interview respondent \#12 (Faculty)

Three respondents who did not hold faculty positions also referred to the respect commanded by faculty. The following response is from an executive director who is at the highest level of university decision-making:

The essential elements of an employment contract are loyalty and subordination - you have to do what your boss tells you. Profs don't.

Interview respondent \#4 (Executive Director)

Comments from two other non-faculty respondents illustrate how faculty are treated as more than just employees of the university. The following quotation is from an administrator in charge of accreditation reviews and assessments:

There is a lot of pressure to not offend faculty. For example, just trying to get a prof to change an outdated textbook is very difficult, if not impossible. Honestly, often we can't do anything about it until he or she leaves... and because we are always worried about offending faculty, we use "please" and "kindly" a lot, and I am always worried about their feelings while I run the review process. Even collecting faculty CVs created an enormous amount of resentment, so much so that we had to ask the unions for permission to collect $C V$ s.

Interview respondent \# 14 (Administrator)

A director, with 25 years of experience in higher education, also commented on the deference with which faculty is treated:

You definitely can't take a "do this because I told you to do it" approach to faculty. You can only very politely request. I call it the academic minuet approach.

Interview respondent \# 15 (Director)

\subsection{Stakeholder Management Strategies}

The stakeholder management strategies employed by university leaders centre largely on themes of open communication, shared goals, working by consensus, partnerships and transparency:

I think that engagement with any of these groups, even when experienced as strong resistance, can inform one's decision-making by contextualizing performance information if you foster genuine dialogue with shared goals in view.

Survey respondent \# 17 (Dean)

I have just started to initiate a culture of assessment here, and we have used the preliminary results in developing partnerships with all of the groups mentioned.

Survey respondent \# 18 (Librarian)

There is no doubt that my stakeholder groups have power, but it is rarely exercised in an effort to leverage an outcome. We work by consensus.

Survey respondent \# 19 (Dean)

I went around to all the faculties and schools and had presentations. I was very direct and open about it.

Interview respondent \# 9 (CFO/Executive Director)

\subsection{Peer Influence as a Stakeholder Management Strategy}

Several respondents commented that, because of the tension between faculty and senior administration, faculty members who understand the importance of PI use would be in a better position to influence non-supportive 
stakeholders:

...PM needs great facilitation skills and also needs some faculty in the group who understand the importance of KPIs and who can then help facilitate that conversation, because faculty are significantly impacted by other faculty and their perspectives...more so than they are affected by executive members... so as a VP Academic, my ability to influence is limited by the confrontational role we see between faculty and administration.

Interview respondent \# 2 (VP Academic)

One respondent suggested that, if warranted, it would be best to let colleagues manage unsupportive academics at the department level, where most academics are located:

Ultimately the younger people or the other people in the department will have to say that it's not in the unit's interest to have colleagues like that.

Interview respondent \#10 (Faculty)

Another respondent stated that academics do not easily comply or listen to institutional edicts. However, the following quote suggests there is a certain level of respect among academics that are in the same profession.

We comply with what our profession tell us we should be. We submit to our profession not the institution.

Interview respondent \#11 (Faculty)

One respondent discussed the increasing level of mistrust, and therefore tension, between faculty and administration:

There are so many more administrators now and I wonder whether it's worth all they money they are being paid. It's definitely not like it used to be. I remember a time when you could just walk into the dean's or even the provost's office. I know a lot of my colleagues take everything the administration says with a grain of salt. Yes, they will ask for our input and participation but often their minds are made up beforehand... so that creates a lot of tension and lack of trust.

\section{Discussion}

The evidence indicates mixed support for PM. Thus, university leaders do not have full support for this initiative and must therefore manage varying stakeholder views. To do so, university leaders use strategies that largely involve notions of open communication, shared goals, working by consensus and partnerships, all of which converge on a central predominant theme of collegiality. Although some studies have indicated that collegiality is on the decline, others have shown that it has endured in academia despite sweeping changes to university practices (Kligyte \& Barrie, 2014). This may very well be the case for the Canadian higher education sector, as it has not fully transitioned to a New Public Management market-based model as quickly as some of its counterparts around the world (Pollanen, 2016), such as the US, UK and Australia. This collegial stakeholder approach is also linked to the notion, supported by the evidence of this study, that faculty members do not view themselves as subordinates to university administrators. Thus, the types of approaches best suited to managing academics may indeed be limited to some variation of the collegial approach. As interview respondent \#10 stated, "if a tenured faculty doesn't want to do something, then one is stuck." This may very well summarize the situation in many universities.

The defensive approach for non-supportive stakeholders, as recommended by the guiding framework (Savage et al., 1991), was not mentioned by any of the respondents. This approach involves tactics used to handle competitors and tries to reduce the dependence on which the stakeholders' interest in the organization is based. However, this is not a realistic approach for the higher education sector with regard to academics. Academics are the operating core of the university, and universities are, and remain, highly dependent on academics to fulfil the basic missions of teaching and research. They are also in the unique position of potentially paralyzing university operations in the event of a strike, as managers and non-academic staff do not have the required skills to take over teaching responsibilities. It must also be noted that when Savage et al. (1991) proposed the framework, the organization they used to illustrate the four possible strategies of involvement, monitoring, collaboration, and defence was the financially-troubled Eastern Airlines, an organization in the private sector in which defensive strategies are commonly used. Therefore, it is not surprising that the defensive approach did not feature in any of the data collected for this study.

The data suggest that peer influence, rather than a defensive strategy, can be utilized to influence non-supportive academics to be more receptive to PM. Indeed, given the long history of tension between senior administrators and 
faculty (De Boy, 2015) this may explain why faculty would likely respond better to one of their peers rather than to an edict from top management. Implementing change has a large social component, where individual readiness to accept change can be shaped by the quality of relationships individuals have with their peers (Stouten et. al (2018). Yet, peer influence, which seems obvious for creating change (Kezar, 2014), has not, to this researcher's knowledge, been identified in any of the stakeholder management literature. Nonetheless, this finding is consistent with the results of previous studies of social networks and peer influence in universities. For example, Hattke et al. (2016) discussed the tremendous role of peer control within academic research groups and argued that membership in these groups is essential to coordinate research activities and to gain access to the reputation awarded by academic colleagues. Thus, it is plausible that peer influence/control may also play a role in non-research activities. As well, Lane et al. (2019) found that social networks in university departments could be potential levers for organizational change and Wang and Hooi (2019) similarly found that peer influence was a motivator for innovation among academics.

Thus, as peer influence is not included in any extant stakeholder management models, but has been demonstrated both in this study and in others mentioned previously to influence academics' viewpoints, a modified stakeholder management model, as shown in Figure 1, is proposed. In the original stakeholder management model (Savage et al., 1991), monitoring was recommended for marginal stakeholders only. In the modified model, monitoring is proposed as the overarching strategy because all stakeholders have the potential to shift from one position to another. This aligns with Preble's (2005) model, which recommends continuous monitoring of all stakeholder positions. Such constant monitoring occurs naturally in higher education, given how most universities are structured. In other words, most university governing bodies include representatives from all major stakeholder groups, allowing senior management to regularly monitor and assess where all major stakeholders stand on any particular issue. As for specific strategies, monitoring is still proposed for marginal stakeholders, though the degree of monitoring should be elevated for this group. Collaborative and involving strategies remain unchanged for mixed-blessing and supportive stakeholders, and a peer influence strategy is proposed for those instances in which a defensive strategy may not be effective. The defensive strategy is maintained in the model, however, as it may be effective for other types of higher education stakeholders such as non-unionized staff, non-academic staff and contract workers.

\section{OVERARCHING STAKEHOLDER MANAGEMENT STRATEGY}

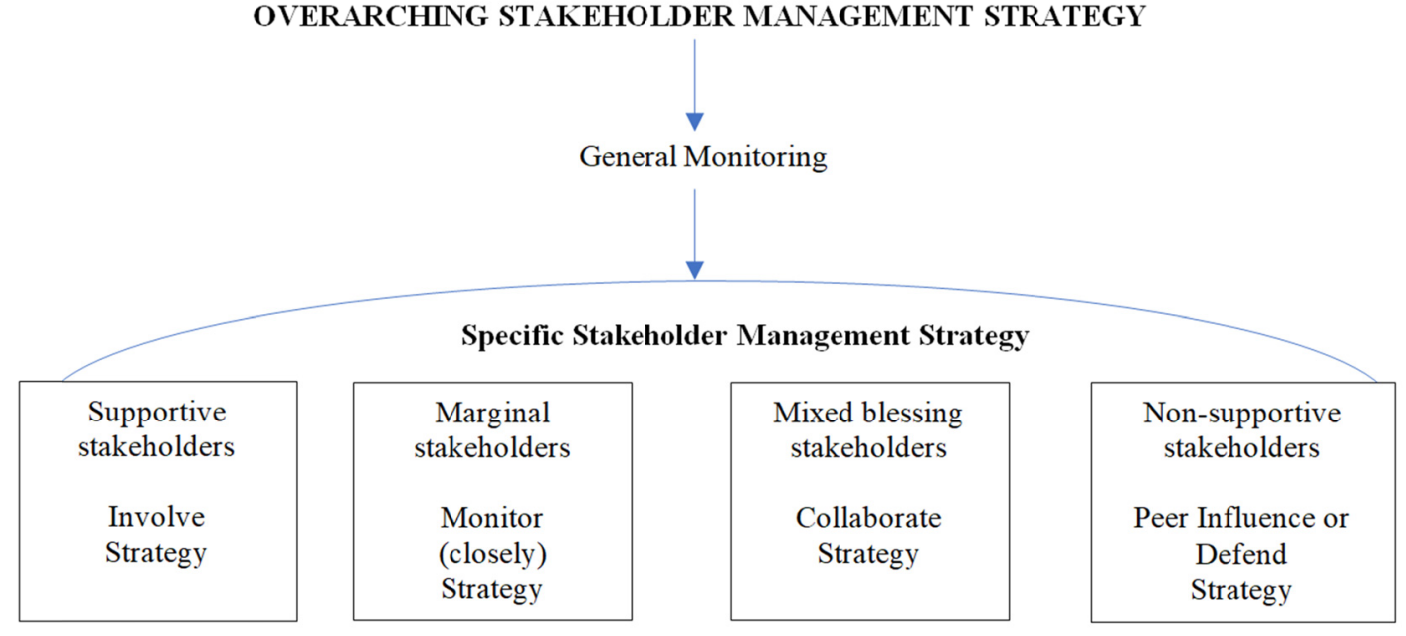

Figure 1. Stakeholder management model for higher education

\section{Limitations and Suggestions for Further Research}

A limitation of this study is that nine of the fifteen individuals interviewed for this project are housed in business schools, which may produce a biased view of PM. Another limitation is that the experiences of the Canadian higher-education sector may not be representative of all higher-education sectors globally. Future research could include perspectives from different academic areas to obtain a more balanced viewpoint and to determine whether there are any differences by discipline, and if so, what those differences are. Future studies could also focus on whether peer influence is carried out as a deliberate attempt by senior administration or whether it occurs naturally, as well as potential alternatives if peer influence is unsuccessful. 


\section{Conclusion}

This study has sought to investigate the stakeholder management strategies that university leaders use to manage faculty views on PM in the Canadian higher education sector. The evidence suggests that the stakeholder management strategies used by university leaders with respect to PM mostly align with the model developed by Savage et al. (1991). The only exception is the absence of the defensive strategy for non-supportive stakeholders, with peer influence used instead to attempt to bring non-supporters on board. Given the distinctive characteristics of most universities, a revised stakeholder management strategy model is proposed, whose overarching strategy is general monitoring of all important stakeholder groups, and specific strategies such as involvement, close monitoring, collaboration, peer influence or defence are used depending on the types of stakeholders under concern.

\section{References}

Aaltonen, K., \& Sivonen, R. (2009). Response strategies to stakeholder pressures in global projects. International Journal of Project Management, 27(2), 131-141. https://doi.org/10.1016/j.ijproman.2008.09.007

Ali, M. A. (2018). Proactive stakeholder practices: A modified reactive, defensive, accommodative, and proactive (RDAP) scale: JMI. Journal of Managerial Issues, 30(4), 405. Retrieved from https://lib-ezproxy.concordia.ca/login?qurl=https $\% 3 \mathrm{~A} \% 2 \mathrm{~F} \% 2 \mathrm{Fwww}$.proquest.com $\% 2$ Fscholarly-journals\% 2Fproactive-stakeholder-practices-modified-reactive\%2Fdocview\%2F2186483719\%2Fse-2\%3Faccountid $\% 3 \mathrm{D} 10246$

Alonso, J. M., Clifton, J., \& Díaz-Fuentes, D. (2015). Did new public management matter? An empirical analysis of the outsourcing and decentralization effects on public sector size. Public Management Review, 17(5), 643-660. https://doi.org/10.1080/14719037.2013.822532

Alvesson, M., \& Spicer, A. (2016). (Un) Conditional surrender? Why do professionals willingly comply with managerialism. Journal of Organizational Change Management, 29(1), 29-45. https://doi.org/10.1108/jocm-11-2015-0221

Andersson, T. D., \& Getz, D. (2008, September). Stakeholder management strategies of festivals. In Journal of Convention \& Event Tourism (Vol. 9, No. 3, pp. 199-220). https://doi.org/10.1080/15470140802323801

Austin-Smith, B. (2020). Universities and colleges headed for a crisis. Retrieved from https://www.caut.ca/latest/2020/11/universities-and-colleges-heading-crisis

Baba, V. V., \& Hakem-Zadeh, F. (2012). Toward a theory of evidence-based decision-making. Management decision, 50(5), 832-867. https://doi.org/10.1108/00251741211227546

Berman, E., \& Wang, X. (2000). Performance measurement in US counties: Capacity for reform. Public Administration Review, 60(5), 409-420. https://doi.org/10.1111/0033-3352.00104

Berman, S. L., Wicks, A. C., Kotha, S., \& Jones, T. M. (1999). Does stakeholder orientation matter? The relationship between stakeholder management models and firm financial performance. Academy of Management journal, 42(5), 488-506. https://doi.org/10.5465/256972

Birdsall, C. (2018). Performance management in public higher education: Unintended consequences and the implications of organizational diversity. Public Performance \& Management Review, 41(4), 669-695. https://doi.org/10.1080/15309576.2018.1481116

Borgianini, F. (1998). Stakeholders' support: the key to getting your ideas implemented. PM Network, 12(2), 46-48. $\quad$ Retrieved from https://www.pmi.org/learning/library/stakeholders-support-key-getting-ideas-implemented

Bourne, M., Mills, J., Wilcox, M., Neely, A., \& Platts, K. (2000). Designing, Implementing and Updating Performance Measurement Systems. International Journal of Operations \& Production Management, 20(7), 754-771. https://doi.org/10.1108/01443570010330739

Casablancas-Segura, C., \& Llonch, J. (2016). Responsive and proactive stakeholder orientation in public universities: antecedents and consequences. Higher education, 72(2), 131-151. https://doi.org/10.1007/s10734-015-9942-2

Cavanaugh, J. (2018). Higher education in the post-degree era. Retrieved from https://www.insidehighered.com/views/2018/06/04/how-higher-ed-has-change-remain-relevant-future-opini on 
CBC News. (2016). University of Manitoba, faculty association hit impasse in mediation. Retrieved from http://www.cbc.ca/news/canada/manitoba/university-manitoba-strike-impasse-mediation-1.3828888

CBC. (2021). An ugly stain for years to come: Laurentian University students, staff reeling from cuts. CBC News. Retrieved

from http://www.cbc.ca/news/canada/sudbury/laurentian-university-job-program-cuts-reaction-1.5984577

Chamorro-Premuzic, T., \& Frankiewicz, B. (2019). Retrieved from https://hbr.org/2019/11/6-reasons-why-higher-education-needs-to-be-disrupted

Chan, G. (2018). Performance information use in the Canadian higher education sector (Doctoral dissertation, Athabasca University, Alberta, Canada). Retrieved from http://hdl.handle.net/10791/264

Chilisa, B., \& Preece, J. (2005). Research methods for adult educators in Africa. Pearson South Africa.

Chinyio, E., \& Olomolaiye, P. (Eds.). (2009). Construction stakeholder management. John Wiley \& Sons. https://doi.org/10.1002/9781444315349

Clarkson, M. E. (1995). A stakeholder framework for analyzing and evaluating corporate social performance. Academy of management review, 20(1), 92-117. https://doi.org/10.5465/amr.1995.9503271994

Cohen, L., Manion, L., \& Morrison, K. (2011). Research methods in education (7th ed.). Routledge.

Craig, R., Amernic, J., \& Tourish, D. (2014). Perverse audit culture and accountability of the modern public university. Financial Accountability \& Management, 30(1), 1-24. https://doi.org/10.1111/faam.12025

De Colle, S. (2005). A stakeholder management model for ethical decision making. International Journal of Management and Decision Making, 6(3-4), 299-314. https://doi.org/10.1504/IJMDM.2005.006555

DeBoy, J. L. (2015). When the corporate storm strikes the academy: Faculty response required. Contemporary Issues in Education Research (CIER), 8(1), 15-18. https://doi.org/10.19030/cier.v8i1.9057

Dennis, M. J. (2020). What needs to change in the reimagined university? Retrieved from https://www.universityworldnews.com/post.php?story=20200918114611781

Dickler, J. (2020, October 26). Falling enrolment, lost tuition puts colleges in extreme financial distress. Retrieved

from https://www.cnbc.com/2020/10/26/falling-enrollment-lost-tuition-puts-colleges-in-financial-distress.html

El-Gohary, N. M., Osman, H., \& El-Diraby, T. E. (2006). Stakeholder management for public private partnerships. International Journal of Project Management, 24(7), 595-604. https://doi.org/10.1016/j.ijproman.2006.07.009

Fischer, E., \& Reuber, R. (2007). The good, the bad, and the unfamiliar: The challenges of reputation formation facing new firms. Entrepreneurship theory and practice, 31(1), 53-75. https://doi.org/10.1111/j.1540-6520.2007.00163.x

Freeman, R. E. (1984). Strategic management: A stakeholder approach. Boston: Pitman Publishing Inc.

Friedman, A. L., \& Miles, S. (2006). Stakeholders: Theory and practice. Oxford University Press on Demand.

Friesen, J. (2020, July 14). Universities scramble to maintain flow of international students and the revenue they bring. $\quad$ Retrieved from http://umsu.ca/news/the-globe-and-mail-canadian-universities-scramble-to-maintain-flow-of-international-s tudents-and-the-revenue-they-bring

Friesen, J. (2021, February 9). Financial health of Ontario universities under scrutiny. Retrieved from https://www.theglobeandmail.com/canada/article-financial-health-of-ontario-universities-under-scrutiny

Frooman, J. (1999). Stakeholder influence strategies. Academy of management review, 24(2), 191-205. https://doi.org/10.5465/amr.1999.1893928

Guba, E. G. (1981). Criteria for assessing the trustworthiness of naturalistic inquiries. ECTJ, 29(2), 75.

Guest, G., Bunce, A., \& Johnson, L. (2006). How many interviews are enough? An experiment with data saturation and variability. Field Methods, 18(1), 59-82. https://doi.org/10.1177/1525822X05279903

Gupta, K., Crilly, D., \& Greckhamer, T. (2020). Stakeholder engagement strategies, national institutions, and firm performance: A configurational perspective. Strategic Management Journal, 41(10), 1869-1900. https://doi.org/10.1002/smj.3204

Harrison, J. S., \& Thompson, S. (2015). Strategic management of healthcare organizations: A stakeholder 
management approach. Business Expert Press.

Hart, S. L., \& Sharma, S. (2004). Engaging fringe stakeholders for competitive imagination. Academy of Management Perspectives, 18(1), 7-18. https://doi.org/10.5465/ame.2004.12691227

Hattke, F., Vogel, R., \& Woiwode, H. (2016). When professional and organizational logics collide: Balancing invisible and visible colleges in institutional complexity. In Multi-level governance in universities (pp. 235-256). Springer, Cham. https://doi.org/10.1007/978-3-319-32678-8_11

Henisz, W. J., Dorobantu, S., \& Nartey, L. J. (2014). Spinning gold: The financial returns to stakeholder engagement. Strategic Management Journal, 35(12), 1727-1748. https://doi.org/10.1002/smj.2180

Honkimäki, S., Jääskelä, P., Kratochvil, J., \& Tynjälä, P. (2021). University-wide, top-down curriculum reform at a Finnish university: perceptions of the academic staff. European Journal of Higher Education, 1-18. https://doi.org/10.1080/21568235.2021.1906727

Kairuz, T., Andriés, L., Nickloes, T., \& Truter, I. (2016). Consequences of KPIs and performance management in higher education. International Journal of Educational Management. https://doi.org/10.1108/ijem-05-2015-0067

Kalfa, S., Wilkinson, A., \& Gollan, P. J. (2018). The academic game: Compliance and resistance in universities. Work, Employment and Society, 32(2), 274-291. https://doi.org/10.1177/0950017017695043

Kallio, K. M., Kallio, T. J., Tienari, J., \& Hyvönen, T. (2016). Ethos at stake: Performance management and academic work in universities. Human Relations, 69(3), 685-709. https://doi.org/10.1177/0018726715596802

Kawamorita, H., Salamzadeh, A., Demiryurek, K., \& Ghajarzadeh, M. (2020). Entrepreneurial universities in times of crisis: Case of COVID-19 pandemic. Journal of Entrepreneurship, Business and Economics, 8(1), 77-88. https://doi.org/10.1080/08276331.2020.1821158

Kenny, J. (2017). Academic work and performativity. Higher Education, 74(5), 897-913. https://doi.org/10.1007/s10734-016-0084-y

Kezar, A. (2014). Higher education change and social networks: A review of research. The Journal of Higher Education, 85(1), 91-125. https://doi.org/10.1080/00221546.2014.11777320

Kimberly, J. R., \& Bouchikhi, H. (2016). Disruption on steroids: Sea change in the worlds of higher education in general and business education in particular. Journal of Leadership \& Organizational Studies, 23(1), 5-12. https://doi.org/10.1177/1548051815606434

Kligyte, G., \& Barrie, S. (2014). Collegiality: Leading us into fantasy-the paradoxical resilience of collegiality in academic leadership. Higher Education Research \& Development, 33(1), 157-169. https://doi.org/10.1080/07294360.2013.864613

Lane, A. K., Skvoretz, J., Ziker, J. P., Couch, B. A., Earl, B., Lewis, J. E., ... \& Stains, M. (2019). Investigating how faculty social networks and peer influence relate to knowledge and use of evidence-based teaching practices. International Journal of STEM Education, 6(1), 1-14. https://doi.org/10.1186/s40594-019-0182-3

Lebas, M. J. (1995). "Performance Measurement and Performance Management." International Journal of Production Economics 41 (1): 23-35. https://doi.org/10.1016/0925-5273(95)00081-X

Lincoln, Y. S., \& Guba, E. G. (1985). Naturalistic inquiry (Vol. 75). Sage Publications, Inc.

Mampaey, J., \& Huisman, J. (2016). Defensive stakeholder management in European universities: An institutional logics perspective. Studies in Higher Education, 41(12), 2218-2231. https://doi.org/10.1080/03075079.2015.1029904

McCusker, K., \& Gunaydin, S. (2015). Research using qualitative, quantitative or mixed methods and choice based on the research. Perfusion, 30(7), 537-542. https://doi.org/10.1177/0267659114559116

McGuckin, A. (2016). University of Manitoba strike ends after Faculty approves new deal. Retrieved from https://globalnews.ca/news/3081135/university-of-manitoba-strike-ends-after-faculty-association-approvesnew-deal/

Miles, M. B., \& Huberman, A. M. (1994). Qualitative data analysis: An expanded sourcebook. Sage Publications, Inc.

Mintzberg, H. (1980). Structure in 5's: A synthesis of the research on organization design. Management Science, 26(3), 322-341. https://doi.org/10.1287/mnsc.26.3.322 
Mitchell, R. K., Agle, B. R., \& Wood, D. J. (1997). Toward a theory of stakeholder identification and salience: Defining the principle of who and what really counts. Academy of Management Review, 22(4), 853-886. https://doi.org/10.5465/amr.1997.9711022105

Oliver, C. (1991). Strategic responses to institutional processes. Academy of management review, 16(1), 145-179. https://doi.org/10.5465/amr.1991.4279002

Parmar, B. L., Freeman, R. E., Harrison, J. S., Wicks, A. C., Purnell, L., \& De Colle, S. (2010). Stakeholder theory: The state of the art. Academy of Management Annals, 4(1), 403-445. https://doi.org/10.5465/19416520.2010.495581

Patria, B. (2012). Change management in the higher education context: A case of student-centred learning implementation. International Journal of Education, 4(4), 176. https://doi.org/10.5296/ije.v4i4.2515

Patton, M. Q. (2002). Qualitative research and evaluation methods (3rd ed.). Sage Publication, Inc.

Phillips, R. A. (1997). Stakeholder theory and a principle of fairness. Business Ethics Quarterly, 51-66. https://doi.org/10.2307/3857232

Pincus, K. V., Stout, D. E., Sorensen, J. E., Stocks, K. D., \& Lawson, R. A. (2017). Forces for change in higher education and implications for the accounting academy. Journal of Accounting Education, 40, 1-18. https://doi.org/10.1016/j.jaccedu.2017.06.001

Pollanen, R. M. (2016). Financial regulation and governance in Canadian higher education. International Journal of Business, Accounting, \& Finance, 10(2), 94-109.

Preble, J. F. (2005). Toward a comprehensive model of stakeholder management. Business and society review, 110(4), 407-431. https://doi.org/10.1111/j.0045-3609.2005.00023.x

Rubin, H. J., \& Rubin, I. S. (2011). Qualitative interviewing: The art of hearing data. Sage Publication, Inc.

Savage, G. T., Nix, T. W., Whitehead, C. J., \& Blair, J. D. (1991). Strategies for assessing and managing organizational stakeholders. Academy of Management Executive, 5(2), 61-75. https://doi.org/10.5465/ame.1991.4274682

Schifrin, M., \& Tucker, H. (2021, February 22). College financial grades 2021: Will your alma mater survive COVID? Retrieved from https://www.forbes.com/sites/schifrin/2021/02/22/college-financial-grades-2021-will-your-alma-mater-survi ve-covid/?sh=675317724916

Schito, J., Jullier, J., \& Raubal, M. (2019). A framework for integrating stakeholder preferences when deciding on power transmission line corridors. EURO J Decis Process 7, 159-195. https://doi.org/10.1007/s40070-019-00100-w

Shenton, A. K. (2004). Strategies for ensuring trustworthiness in qualitative research projects. Education for Information, 22(2), 63-75. https://doi.org/10.3233/EFI-2004-22201

Stouten, J., Rousseau, D. M., \& De Cremer, D. (2018). Successful organizational change: Integrating the management practice and scholarly literatures. Academy of Management Annals, 12(2), 752-788. https://doi.org/10.5465/annals.2016.0095

Teddlie, C., \& Yu, F. (2007). Mixed methods sampling: A typology with examples. Journal of Mixed Methods Research, 1(1), 77-100. https://doi.org/10.1177/1558689806292430

Thompson, B. S., \& Friess, D. A. (2019). Stakeholder preferences for payments for ecosystem services (PES) versus other environmental management approaches for mangrove forests. Journal of environmental management, 233, 636-648. https://doi.org/10.1016/j.jenvman.2018.12.032

Wang, J., \& Hooi, R. (2019). The moderation effect of workplace experience on innovation motivation: A study of STEM faculty in Singapore. Technology Analysis \& Strategic Management, 31(7), 862-874. https://doi.org/10.1080/09537325.2019.1566524

Waritimi, E. (2012). Stakeholder management in practice: Evidence from the Nigerian oil and gas industry (Doctoral dissertation, Durham University). Retrieved from http://etheses.dur.ac.uk/3558/2/Waritimi\%2C_E_

Yamane, T., \& Kaneko, S. (2021). Impact of raising awareness of Sustainable Development Goals: A survey experiment eliciting stakeholder preferences for corporate behavior. Journal of Cleaner Production, 285, 125291. https://doi.org/10.1016/j.jclepro.2020.125291 


\section{Copyrights}

Copyright for this article is retained by the author(s), with first publication rights granted to the journal.

This is an open-access article distributed under the terms and conditions of the Creative Commons Attribution license (http://creativecommons.org/licenses/by/4.0/). 